\title{
Kompetensi Pedagogik Guru PPKN dalam Proses Pembelajaran di SMP Negeri 1 Painan Kabupaten Pesisir Selatan
}

\author{
Indri Okta Sari, Junaidi Indrawadi, Al Rafni \\ Program Studi Pendidikan Pancasila dan Kewarganegaraan \\ Universitas Negeri Padang \\ E-mail: indrioktasari10@gmail.com
}

\begin{abstract}
ABSTRAK
Guru harus memiliki dan menguasai kompetensi pedagogik dalam mewujudkan pembelajaran yang efektif, kreatif, menyenangkan, dan bermakna bagi peserta didik dilihat dari sepuluh aspek kompetensi pedagogik. Namun dalam proses pembelajaran siswa kurang memperhatikan pembelajaran dikarenankan guru kurang menarik dan bersifat menonton dalam memberikan pembelajaran. Penelitian ini bertujuan Untuk Melihat Gambaran Kompetensi Pedagogik Guru PPKn Dalam Proses Pembelajaran di SMP Negeri 1 Painan Kabupaten Pesisir Selatan dilihat dari sepuluh aspek kompetensi pedagogik. Penelitian ini menggunakan pendekatan Deskriptif Kuantitatif untuk melihat, mengambarkan keadaan, dan sebagaimana adanya yang terdapat dilapangan. Lokasi penelitian ini adalah di SMP Negeri 1 Painan Kabupaten Pesisir Selatan. Populasi penelitian ini adalah siswa kelas VIII dan IX di SMP Negeri 1 Painan Kabupaten Pesisir Selatan terdiri dari 461 siswa. Teknik penarikan sampel menggunakan Sample random sampling dengan jumlah responden 82 orang dengan menggunakan rumus Slovin. Pengumpulan data dalam penelitian ini merupakan penyebaran angket sebanyak 40 butir pertanyaan dengan menggunakan Skala Likert. Analisis data yang digunakan adalah analisis statistik deskriptif dengan hitungan persentase. Berdasarkan hasil penelitian, secara keseluruhan kompetensi pedagogik guru PPKn dalam proses pembelajaran di SMP Negeri 1 Painan Kabupaten Pesisir Selatan yaitu dengan TCR yang diperoleh 78,95\%. Sehingga dapat disimpulkan bahwa jawaban siswa kelas VIII dan IX dilihat dari sepuluh aspek kompetensi pedagogik sudah baik.
\end{abstract}

\section{Kata Kunci : Kompetensi Pedagogik, Proses Pembelajaran}

\section{ABSTRACT}

Teachers must possess and master pedagogical competencies in realizing effective, creative, fun, and meaningful learning for students seen from ten aspects of pedagogic competence. But in the learning process students pay less attention to learning because the teacher is less attractive and is watching in providing learning. This study aims to see the description of the pedagogical competencies of PPKn teachers in the learning process in Painan 1 Middle School in South Coastal District viewed from ten aspects of pedagogic competence. This study uses a Quantitative Descriptive approach to see, describe the situation, and as it is in the field. The location of this study is in the Painan 1 Middle School in South Coastal District. The population of this study was students of class VIII and IX at the Painan 1 Middle School in South Coastal District consisting of 461 students. The 
sampling technique uses Sample random sampling with the number of respondents 82 people using the Slovin formula. Data collection in this study is 40 questionnaires by using a Likert Scale. The data analysis used is descriptive statistical analysis with a percentage count. Based on the results of the study, overall the pedagogical competence of the PPKn teachers in the learning process in Painan 1 Middle School in South Coastal District was TCR obtained $78.95 \%$. So that it can be concluded that the answers of class VIII and IX students seen from ten aspects of pedagogical competence are good.

Keywords : Pedagogic Competence, Learning Process.

\section{PENDAHULUAN}

Kualitas pendidikan di Indonesia jauh dari kata memadai dikarenakan kualitas guru masih bermasalah. Maka perlunya perbaikan kualitas guru untuk memperbaiki kualitas pendidikan. Salah satu penyebab rendahnya kualitas guru disebabkan oleh kompetensi guru yang belum memenuhi Standar Kompetensi Minimal. Hal ini dapat dilihat dari hasil Uji Kompetensi Guru (UKG) tiga tahun terakhir sejak tahun 2015 yang mulai meningkat pada tahun 2016, namun angka rata-ratanya hingga tahun 2017 masih dibawah 70, untuk semua jenjang pendidikan dasar dan menenggah (beritatagar.id). Pelaksanaan UKG ini berfokus pada kemampuan guru dalam menguasai kompetensi pedagogik dan kompetensi profesional, yang pada dasarnya kompetensi pedagogik menurut Rifma (2016:56) adalah seperangkat pengetahuan, keterampilan, dan perilaku yang harus dimiliki guru dalam mewujudkan pembelajaran yang aktif, kreatif, efektif, menyenangkan, dan bermakna bagi peserta didik. Kompetensi pedagogik guru ini penting untuk memenuhi kebutuhan pelaksanaan proses pembelajaran. Namun sering terdapat permasalahan yang perlu dicarikan solusinya, permasalahan ini dapat dilihat dari fenomena-fenomena yang terjadi dalam proses pembelajaran, yaitu guru kurang menguasai karakteristik karakteristik peserta didik, guru kurang memvariasikan metode pembelajaran, guru kurang kreatif menciptakan suasana pembelajaran yang menyenangkan, dan penilaian daan evaluasi yang kurang. Sehingga menimbulkan pandangan peserta didik yang berbeda-beda terhadap guru.

Kompetensi pedagogik ini sudah banyak dibahas dalam beberapa penelitian terdahulu yaitu (Rifma, 2013) menyatakan problematika kompetensi pedagogik guru dalam merencanakan pembelajaran masih banyak ditemukan guru yang belum menyusun perencanaan pembelajaran, tidak mengunakan media pembelajaran, metode yang kurang bervariasi, kurang melibatkan siswa dalam pembelajaan, dan evaluasi yang dilakukan guru masih menggunakan soal yang ada dalam buku teks. Hal ini juga dinyatakan oleh (Andriawati, 2013) yaitu terdapat pengaruh kompetensi pedagogik guru terhadap hasil belajar sebesar 43,3\%. Selanjutnya juga diungkapkan oleh (Anifa Alfia Nur,2014) bahwa tingkat kompetensi pedagogik guru Sekolah Dasar di Yayasan Mutiara Gambut dapat 
dikatakan baik. Menurut Agusnita (2015) kompetensi pedagogik guru senior lebih baik dari kompetensi pedagogik guru junior. Sedangkan menurut Ninik Sumiarsi (2015) kompetensi pedagogik yang dimiliki guru SDN 041 Tarakan sudah sejalan dengan Peraturan Menteri Pendidikan Nasional No. 16 tahun 2007 dan perlu ada perbaikan dan peningkatan.

Penelitian ini memiliki perbedaan dengan penelitian sebelumnya dimana penelitian ini membahas pandangan siswa tentang kompetensi pedagogik guru PPKn dalam proses pembelajaran. Sedangkan penelitian sebelumnya membahas problematika kompetensi pedagogik guru dan upaya peningkatan kompetensi pedagogik guru. Sehingga dengan adanya berbagai problem atau permasalahan ini maka perlu diatasi dengan melakukan perbaikan dan melakukan upaya peningkatan baik itu dari guru maupun kepala sekolah.

Topik ini membahas berbagai persoalan dan permasalahan yang terjadi di kalangan guru-guru di SMP Negeri 1 Painan Kabupaten Pesisir Selatan. Berdasarkan hasil observasi dilapangan banyak diantara siswa yang beranggapan guru dalam proses pembelajaran kurang menarik dalam menyampaikan pembelajaran, bersifat menonton, metode pembelajaran kurang bervariasi, kurang dengan dekat siswa, serta dalam evaluasi guru tidak memberikan penilaian secara langsung. Hal ini menyebabkan siswa pasif dalam belajar karena guru yang kurang memperhatian kebutuhan siswa.

Keterbatasan solusi yang pernah ditawarkan dalam artikel ini adalah memberikan upaya peningkatan kompetensi pedagogik yang dilakukan oleh guru dan kepala sekolah. Upaya guru dalam meningkatkan proses pembelajaran yaitu mengikuti organisasi-organisasi keguruan dan mengikuti kursus kependidikan. Upaya lembaga pendidikan atau kepala sekolah dalam meningkatkan kompetensi pedagogik guru dengan mengadakan lokakarya, mengadakan penataran guru, memotivasi guru untuk membuat karya tulis ilmiah, memberikan penghargaan, mengadakan supervisi, dan mengadakan rapat sekolah.

Kompetensi pedagogik dalam proses pebelajaran ini memberikan solusi dalam artikel ini yaitu memberikan pelatihan-pelatihan kepada setiap guru dengan menerapkannya sepuluh aspek kompetensi pedagogik dalam proses pembelajaran dan memberikan penilaian terkait aspek yang belum atau masih perlu perbaiki. Lembaga pendidikan juga harus ikut berperan dalam memantau dan memberikan penilaian dalam menerapkan sepuluh aspek kompetensi pedagogik berdasarkan Peraturan Menteri Pendidikan Nasional Republik Indonesia No. 16 Tahun 2007 tentang Standar Kualifikasi Akademik dan Kompetensi Guru.

Tujuan dalam artikel ini adalah untuk mengetahui gambaran kompetensi pedagogik guru PPKn dalam proses pembelajaran di SMP Negeri 1 Painan Kabupaten Pesisir Selatan. Penelitian ini dilakukan guna untuk melihat, mengetahui pendapat atau tanggapan siswa tentang kompetensi pedagogik guru dalam proses pembelajaran. Sehingga guru 
dapat memperbaiki kompetensi pedagogik yang dimilikinya dan mempertahankan serta meningkatkannya untuk menciptakan guru yang berkualitas dan memperbaiki kualitas pendidikan.

\section{METODE PENELITIAN}

Metode penelitian ini adalah penelitian Deskriptif Kuatitatif. Lokasi penelitian ini dilakukan di SMP Negeri 1 Painan Kabupaten Pesisir Selatan. Populasi penelitian adalah siswa kelas VIII dan IX SMP Negeri 1 Painan Kabupaten Pesisir Selatan berjumlah 461 orang. Sampel penelitian 82 responden ditentukan menggunakan rumus Slovin $\left(\mathrm{s}=\frac{N}{1+N \cdot e^{2}}\right)$. Instrumen penelitian yang digunakan berupa angket dalam bentuk skla Likert dengan empat alternatif jawaban yaitu: Sangat Setuju (SS), Setuju (S), Tidak Setuju (TS), dan Sangat Tidak Setuju (STS). Data diolah dengan menghitung frekuensi presentase $\left(\mathrm{P}=\frac{F}{N} \times 100 \%\right)$ dan menentukan rata-rata (mean) dari masing-masing skor jawaban responden dengan rumus $\left(\right.$ mean $\left.=\frac{4(S S)+3(S)+2(T S)+1(S T S)}{N}\right) \quad$ serta menentukan Tingkat Capaian Responden (TCR) pada setiap pertanyaan rumus yang digunakan

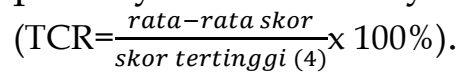

\section{HASIL DAN PEMBAHASAN}

\section{Menguasai Karakteristik Peserta Didik}

Hasil keseluruhan pada jawaban siswa tentang kompetensi pedagogik guru PPKn dalam menguasai karakteristik peserta didik yaitu $42,92 \%$ siswa yang menjawab Sangat Setuju (SS), 36,66\% siswa yang menjawab Setuju (S), 18,06\% siswa yang menjawab Tidak Setuju (TS), 2,44 siswa yang menjawab Sangat Tidak Setuju (STS). Rata-rata dalam menguasai karakteriktik peserta didik ini adalah 3,2 dengan TCR yang diperoleh 79,95\%. Sehingga dapat disimpulkan bahwa jawaban dari siswa tentang kompetensi pedagogik guru PPKn dalam menguasai karakteristik peserta didik ini adalah baik. Untuk lebih rinci dapat dilihat pada grafik.

Gambar 2.1

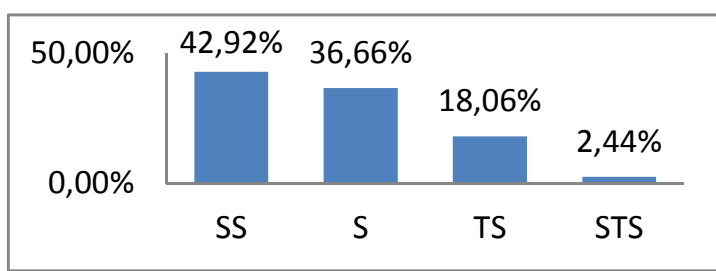

Berdasarkan hasil penelitian yang dilakukan kepada siswa kelas VIII dan IX SMP Negeri 1 Painan tentang kompetensi pedagogik guru PPKn dalam menguasai karakteristik pesertadidik menunjukan bahwa secara keseluruhan guru PPKn telah menguasai karakteristik peserta didik dengan baik. Dalam menguasai karakteristik siswa, menurut Sukmadinata dalam Musfah $(2011 ; 31)$ guru harus mengenal dan memahami siswa dengan baik, memahami tahap perkembangan yang telah dicapainya, kemampuannya, keunggulan dan kekurangannya, hambatan yang dihadapi serta faktor dominan yang mempengaruhinya. Guru PPKn di SMP Negeri 1 Painan telah berupaya mengenal dan mengetahui nama siswa serta memahami karakter siswa dalam belajar dengan baik. Hal ini dapat dilihat dari guru PPKn yang mengenal dan mengetahui nama siswanya dan bisa membedakan siswa yang aktif 
dalam belajar maupun siswa yang pasif dalam belajar.

2. Menguasai Teori Belajar dan PrinsipPrinsip Pembelajaran Yang Mendidik Hasil keseluruhan pada jawaban siswa tentang kompetensi pedagogik guru PPKn dalam menguasai teori belajar dan prinsip-prinsip pembelajaran yang mendidik yaitu $33,85 \%$ siswa yang menjawab Sangat Setuju (SS), 40,25\% siswa yang menjawab Setuju (S), 22,25\% siswa yang menjawab Tidak Setuju (TS), 3,65\% siswa yang menjawab Sangat Tidan Setuju (STS). Rata-rata dalam menguasai teori belajar dan prinsipprinsip pembelajaran yang mendidik ini adalah 3,04 dengan TCR yang diperoleh 76,06\%. Sehingga dapat disimpulkan bahwa jawaban dari siswa tentang kompetensi pedagogik guru PPKn dalam menguasai teori belajar dan prinsip-prinsip pembelajaran yang mendidik ini adalah baik. Untuk lebih rinci dapat dilihat pada grafik.

Gambar 2.2

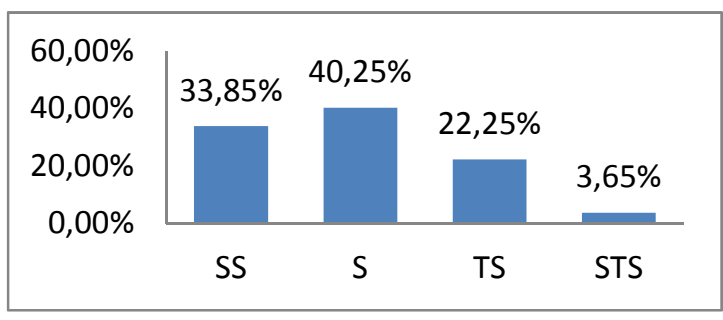

Berdasarkan hasil penelitian yang dilakukan kepada siswa kelas VIII dan IX SMP Negeri 1 Painan tentang kompetensi pedagogik guru PPKn dalam Menguasai teori belajar dan prinsip-prinsip pembelajaran yang mendidik menunjukan secara keseluruhan guru PPKn telah menguasai teori belajar dan prinsipprinsip pembelajaran dengan baik.
Menurut (Nur, 2014) guru harus mampu menetapkan berbagai pendekatan, strategi, metode, dan teknik pembelajaran yang mendidik secara kreatif dan tidak membosankan serta guru mampu menyesuaikan metode dengan karakteristik belajar siswa. Hal ini dapat dilihat dari guru PPKn memberikan pembelajaran dengan mengunakan metode pembelajaran yang mendidik, namun perlu ditingkatkan dan divariasikan agar siswa tidak bosan dan bersemangat dalam belajar.

3. Mengembangkan Kurikulum Yang Terkait Dengan Mata Pelajaran Yang Diampu

Hasil keseluruhan pada jawaban siswa tentang kompetensi pedagogik guru PPKn dalam mengembangkan kurikulum yang terkait dengan mata pelajaran yang diampu yaitu 35,35\% siswa yang menjawab Sangat Setuju (SS), 53,35\% siswa yang menjawan Setuju (S), 9,47\% siswa yang menjawab Tidak Setuju (TS), dan 1,82\% siswa yang menjawab Sangat Tidak Setuju (STS). Rata-rata dalam mengembangan kurikulum ini adalah 3,22 dengan TCR yang diperoleh $80,56 \%$ sehingga dapat disimpulkan bahwa jawaban dari siswa tentang kompetensi pedagogik guru PPKn dalam mengembangakan kurikulum yang terkait dengan mata pelajaran yang diampu ini adalah baik. Untuk lebih rinci dapat dilihat pada grafik.

Gambar 2.3

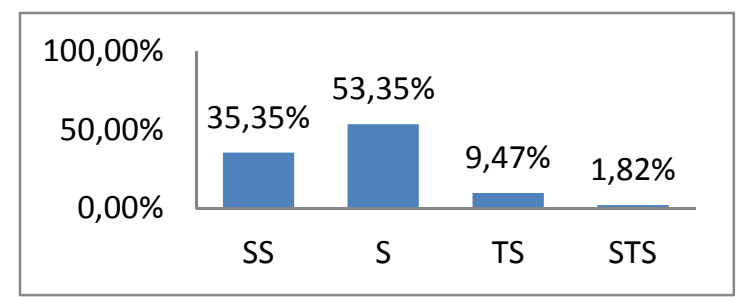


Berdasarkan hasil penelitian yang dilakukan kepada siswa kelas VIII dan IX SMP Negeri 1 Painan tentang kompetensi pedagogik guru PPKn dalam mengembangkan kurikulum yang terkait dengan mata pelajaran yang diampu menunjukan secara keseluruhan guru PPKn telah mengembangan kurikulum dengan baik. Guru diharapkan membimbing dan mengarahkan pengembangan kurikulum dan pembelajaran secara efektif dan efesien, serta melakukan pengawasan dan pelaksanaannya (Rifma, 2016:76). Guru mampu menyusun silabus berdasarkan kurikulum dan membuat Rencana Pelaksanaan Pembelajaran (RPP) sesuai dengan tujuan pembelajaran yang dicapai. Hal ini dapat dilihat dari guru PPKn mempunyai RPP sebagai pedoman dalam melakukan proses pembelajaran, namun masih perlu dikembangkan agar kebutuhan siswa tercapai dan guru PPKn telah menata materi pembelajaran dengan baik.

\section{Menyelenggarakan Pembelajaran Yang Mendidik}

Hasil keseluruhan pada jawaban siswa tentang kompetensi pedagogik guru PPKn dalam menyelenggarakan pembelajaran yang mendidik yaitu $39,52 \%$ siswa yang menjawab Sangat Setuju (SS), 49,74\% siswa yang menjawab Setuju (S), 10\% siswa yang menjawab Tidak Setuju (TS), dan $0,74 \%$ siswa yang menjawab Sangat Tidak Setuju (STS). Rata-rata dalam menyelenggarakan pembelajaran yang mendidik ini adalah 3,28 dengan TCR yang diperoleh $82 \%$. Sehingga dapat disimpulkan bahwa jawaban dari siswa tentang kompetensi pedagogik guru PPKn dalam menyelenggarakan pembelajaran yang mendidik ini adalah sangat baik. Untuk lebih rinci dapat dilihat pada grafik.

\section{Gambar 2.4}

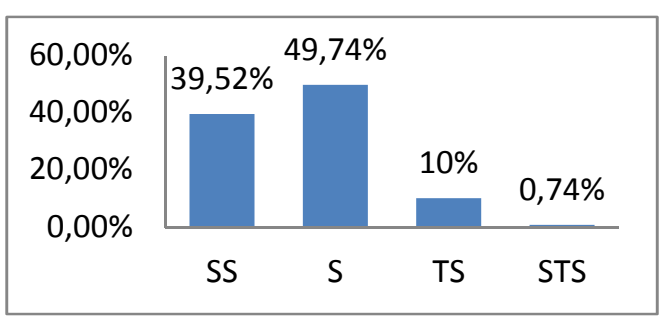

Berdasarkan hasil penelitian yang dilakukan kepada siswa kelas VIII dan IX SMP Negeri 1 Painan tentang kompetensi pedagogik guru PPKn dalam menyelenggarakan pembelajaran yang mendidik menunjukan secara keseluruhan guru PPKn telah menyelenggarakan pembelajaran yang mendidik dengan sangat baik. Guru harus mampu menciptakan dan menumbuhkan situasi pembelajaran yang kondusif sesuai dengan rencana yang telah dan disusun. Guru dapat menciptakan suasana yang menyenangkan, sehingga potensi peserta didik dapat berkembangan dengan baik. Guru PPKn di SMP Negeri 1 Painan telah berupaya menciptakan suasana pembelajaran yang menyenangkan dengan keaktifan dan kreativitas guru dalam menyusun rencana pembelajaran.

\section{Memanfaatkan Teknologi Informasi dan Komunikasi Untuk Kepentingan Pembelajaran}

Hasil keseluruhan pada jawaban siswa tentang kompetensi pedagogik guru PPKn dalam memanfaatkan teknologi informasi dan komunikasi untuk kepentingan pembelajaran yaitu 
29,75 siswa yang menjawab Sangat Setuju (SS), 43,1\% siswa yang menjawab Setuju (S), 23,6\% siswa yang menjawab Tidak Setuju (TS), dan 3,6\% siswa yang menjawab Sangat Tidak Setuju (STS). Rata-rata dalam memanfaatkan teknologi informasi dan komunikasi untuk kepentingan pembelajaran ini 2,98 dengan TCR yang diperoleh $74,6 \%$. Sehingga dapat disimpulkan bahwa jawaban dari siswa tentang kompetensi pedagogik guru PPKn dalam memanfaatkan teknologi informasi dan komunikasi untuk kepentingan pembelajaran ini adalah baik. Untuk lebih rinci dapat dilihat pada grafik.

Gambar 2.5

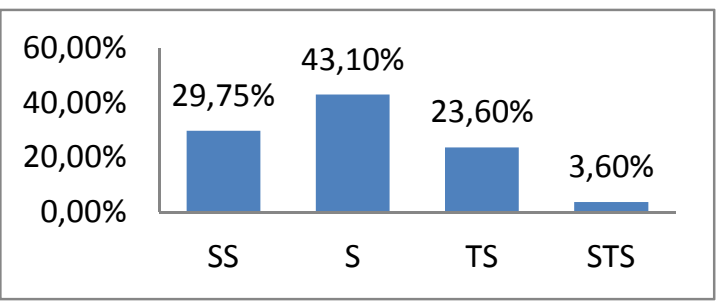

Berdasarkan hasil penelitian yang dilakukan kepada siswa kelas VIII dan IX SMP Negeri 1 Painan tentang kompetensi pedagogik guru PPKn dalam memanfaatkan teknologi informasi dan komunikasi untuk kepentingan pembelajaran menunjukan secara keseluruhan guru PPKn telah memanfaatkan teknologi informasi dan komunikasi dengan baik. Guru mampu menggunakan teknologi informasi dan komunikasi seperti in focus/ LCD proyektor dalam menayangkan gambar atau video untuk menarik perhatian siswa dalam belajar, namun masih ada guru PPKn jarang menggunakan in focus dalam belajar karena keterbatasannya. Penggunaan teknologi tujuannya untuk memudahkan guru dalam kegiataan pembelajaran, namun teknologi bukanlah syarat dalam meningkatkan kualitas pendidikan disekolah.

\section{Memfasilitasi Pengembangan Potensi Peserta Didik Untuk Mengaktualisasikan Berbagai Potensi Yang Dimiliki \\ Hasil keseluruhan pada jawaban} siswa tentang kompetensi pedagogik guru PPKn dalam memfasilitas pengembangan potensi peserta didik untuk mengaktualiasikan berbagai potensi yang dimiliki yaitu 27,42\% siswa yang menjawab Sangat Setuju (SS), 50,3\% siswa yang menjawab Setuju (S), 19,5\% siswa yang menjawab Tidak Setuju (TS), dan 2,72\% siswa yang menjawab Sangat Tidak Setuju (STS). Rata-rata dalam memfasilitas pengembangan potensi peserta didik untuk mengaktualiasikan berbagai potensi yang dimiliki ini adalah 3,02 dengan TCR yang diperoleh $75,68 \%$. Sehingga dapat disimpulkan bahwa jawaban dari siswa tentang kompetensi Pedagogik guru PPKndalam memfasilitas pengembangan potensi peserta didik untuk mengaktualiasikan berbagai potensi yang dimiliki ini adalah baik. Untuk lebih rinci dapat dilihat pada grafik.

Gambar 2.6

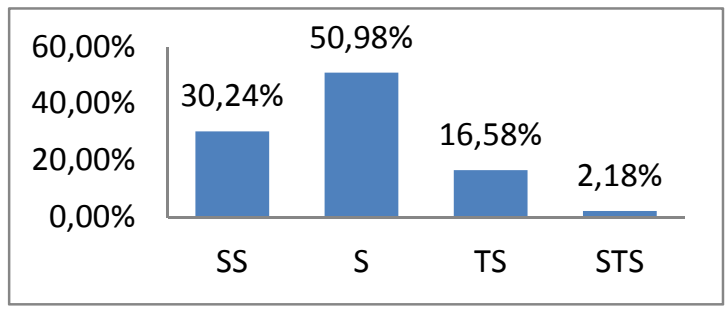

Berdasarkan hasil penelitian yang dilakukan kepada siswa kelas 
VIII dan IX SMP Negeri 1 Painan tentang kompetensi pedagogik guru PPKn dalam memfasilitas pengembangan potensi peserta didik untuk mengaktualisasikan berbagai potensi yang dimiliki menunjukkan secara keseluruhan guru PPKn telah memfasilitas pengembangan potensi peserta didik dengan baik. Guru PPKn berupaya memberikan motivasi dan semangat serta membantu kesulitan siswa dalam belajar untuk mengembangkan potensi yang dimiliki siswa. Misalnya guru membantu mengembangakan kemampuan yang dimiliki siswa dalam bidang pramuka, kesenian dan lain sebagainya.

\section{Berkomunikasi Secara Efektif, Empatik, dan Santun Dengan Peserta Didik}

Hasil keseluruhan pada jawaban siswa tentang kompetensi pedagogik guru PPKn dalam berkomunikasi secara efektif, empati, dan santun dengan peserta didik yaitu 56,72\% siswa yang menjawab Sangat Setuju (SS), 35,05\% siswa yang menjawab Setuju (S), 7,65\% siswa yang menjawab Tidak Setuju (TS), dan 0,6\% siswa yang menjawab Sangat Tidak Setuju (STS). Rata-rata dalam berkomunikasi secara efektif, empati, dan santun dengan peserta didik ini adalah 3,48 dengan TCR yang diperoleh 87\%. Sehingga dapat disimpulkan bahwa jawaban dari siswa tentang kompetensi pedagogik guru PPKn dalam berkomunikasi secara efektif, empati, dan santun dengan peserta didik ini adalah sangat baik. Untuk lebih rinci dapat dilihat pada grafik.

Gambar 2.7

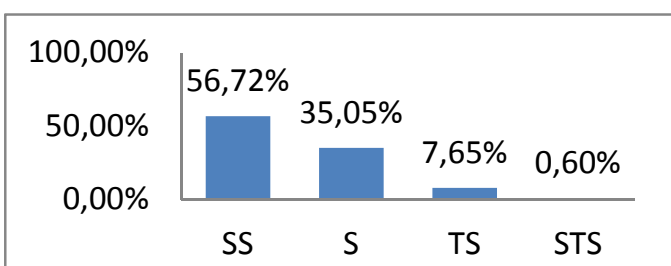

Berdasarkan hasil penelitian yang dilakukan kepada siswa kelas VIII dan IX SMP Negeri 1 Painan tentang kompetensi pedagogik guru PPKn dalam berkomunikasi secara efektif, empati, dan santun dengan peserta didik menunjukan secara keseluruhan guru PPKn telah berkomuniasi secara efektif, empati, dan santun kepada siswa dengan sangat baik.Guru PPKn mampu berkomunikasi dengan baik dalam merespon dan menjelaskan materi pembelajaran dikelas, sehingga siswa dapat mengerti dengan penjelasan guru.

\section{Menyelenggarakan Penilaian dan Evaluasi Proses dan Hasil Belajar}

Hasil keseluruhan pada jawaban siswa tentang kompetensi pedagogik guru PPKn dalam menyelenggarakan penilaian dan evaluasi proses dan hasil belajar yaitu $31,3 \%$ siswa yang menjawab Sangat Setuju (SS), 41,5\% siswa yang menjawab Setuju (S), 15,86 siswa yang menjawab Tidak Setuju (TS), dan 11,36\% siswa yang menjawab Sangat Tidak Setuju (STS). Rata-rata dalam menyelenggarakan penilaiandan evaluasi proses dan hasil belajar ini adalah 2,92 dengan TCR yang diperoleh 73,16\%. Sehingga dapat disimpulkan bahwa jawaban dari siswa tentang kompetensi pedagogik guru PPKn dala menyelenggarakan penilaian dan evaluasi proses dan hasil belajar ini adalah baik. Untuk lebih rinci dapat dilihat pada grafik. 
Gambar 2.8

Berdasarkan hasil penelitian yang dilakukan kepada siswa kelas VIII dan IX SMP Negeri 1 Painan tentang kompetensi pedagogik guru PPKn dalam menyelenggakan penilaian dan evaluasi proses dan hasil belajar menunjukan secara keseluruhan guru PPKn telah menyelenggakan penilaian dan evaluasi dengan baik. Menurut Sutisna dalam Rifma (2016:83) mengemukakan bahwa penilaian proses pembelajaran dilaksanakan untuk mengetahui keberhasilan perencanaan kegiatan belajar mengajar yang telah disusun dan dilaksanakan. Penilaian ini bertujuan untuk mendapatkan informasi yang akurat mengenai tingkat pencapaian siswa, sehingga tindak lanjut hasil belajar dapat diupayakan dan dilaksanakan. Guru PPKn berupaya melakukan penilaian dan evaluasi dengan adil dan sesuai dengan kemampuan yang dimiliki siswa. Misalnya guru PPKn telah melakukan tugas dan ulangan kepada siswa dikelass.

\section{Memanfaatkan Hasil Penilaian dan Evaluasi Untuk Kepentingan Pembelajaran}

Hasil keseluruhan pada jawaban siswa tentang kompetensi pedagogik guru PPKn dalam memanfaatkan hasil penilaian dan evaluasi untuk kepentingan pembelajaran yaitu 46,3\% siswa yang menjawab Sangat Setuju (SS), 43,1\% siswa yang menjawab Setuju (S), 8,56\% siswa yang menjawab Tidak Setuju (TS), dan 2,03\% siswa yang menjawab Sangat Tidak Setuju
(STS). Rata-rata dalam memanfaatkan

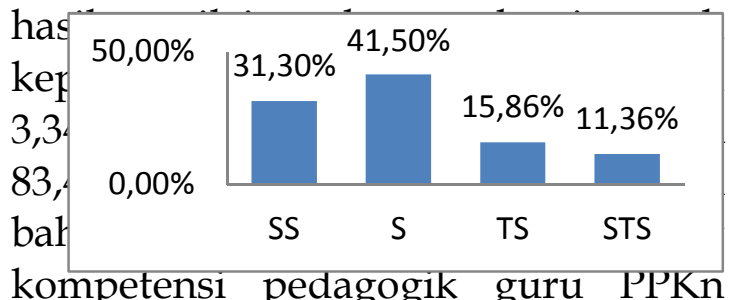

dalam memanfaatkan hasil penilaian dan evaluasi untuk kepentingan pembelajaran ini adalah sangat baik. Untuk lebih rinci dapat dilihat pada grafik.

Gambar 2.9

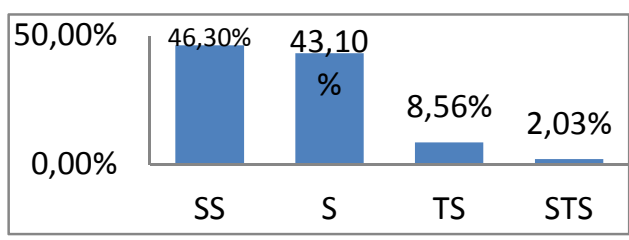

Berdasarkan hasil penelitian yang dilakukan kepada siswa kelas VIII dan IX SMP Negeri 1 Painan tentang kompetensi pedagogik guru PPKn dalam memanfaatkan hasil penilaian dan evaluasi untuk kepentingan pembelajaran menunjukan secara keseluruhan guru PPKn telah memanfaatkan hasil penilaian dan evaluasi dengan sangat baik. Guru PPKn telah melakukan evaluasi atas efektivitas proses dan hasil belajar yang kemudian menggunakan hasil penilaian dan evaluasi untuk merancang program pengayaan dan remedial bagi siswa yang berhasil maupun tidak berhasil dalam belajar.

\section{Melakukan Tindakan Reflektif Untuk Meningkatkan Kualitas Pembelajaran}

Hasil keseluruhan pada jawaban siswa tentang kompetensi pedagogik guru PPKn dalam melakukan tindakan 
reflektif untuk meningkatkan yaitu $34,45 \%$ siswa yang menjawab Sangat Setuju (SS), 42,07\% siswa yang menjawab Setuju (S), 21,05\% siswa yang menjawab Tidak Setuju (TS), dan $2,42 \%$ siswa yang menjawab Sangat Tidak Setuju (STS). Rata-rata dalam melakukan tindakan reflektif untuk meningkatkan kualitas pembelajaran ini adalah 3,08 dengan TCR yang diperoleh 77,12\%. Sehingga dapat disimpulkan bahwa jawaban dari siswa tentang kompetensi pedagogik guru PPKn dalam melakukan tindakan reflektif untuk meningkatkan kualitas pembelajaran ini adalan baik. Untuk lebih rinci dapat dilihat pada grafik.

Gambar 2.10

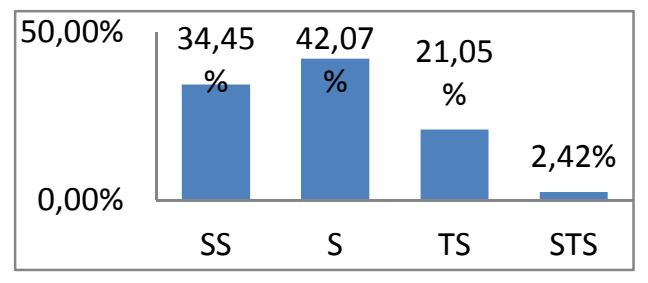

Berdasarkan hasil penelitian yang dilakukan kepada siswa kelas VIII dan IX SMP Negeri 1 Painan tentang kompetensi pedagogik guru PPKn dalam melakukan tindakan reflektif untuk meningkatkan kualitas pembelajaran menunjukan secara keseluruhan guru PPKn telah melakukan tindakan reflektif untuk meningkatkan kualitas pembelajaran dengan baik. Guru PPKn berupaya melakukan penilaian terhadap pembelajaran yang telah dilaksanakan dan mengatasi kekurangan yang terdapat dalam proses pembelajaran agar dapat meningkatkan kualitas pendidikkan.
Kompalasi Kualifikasi Kompetensi Pedagogik Guru PPKn Dalam Proses Pembelajaran di SMP Negeri 1 Painan Kabupaten Pesisir Selatan 2.11

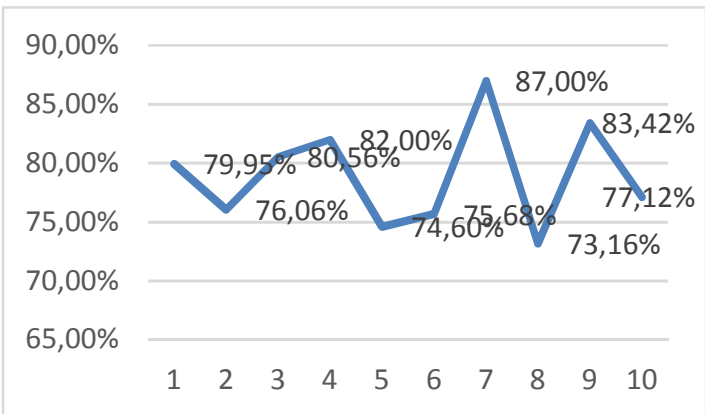

Berdasarkan grafik diatas, mengenai kompetensi pedagogik guru PPKn dalam proses pembelajaran pada sepuluh indikator memperoleh hasil yang telah dihitung dengan menentukan Tingkat Capaian Responden (TCR). Dimana, dari sepuluh indikator terdapat tiga kategori sangat baik dan tujuh kategori baik.

\section{KESIMPULAN}

Berdasarkan hasil penelitian tentang "Kompetensi Pedagogik Guru PPKn Dalam Proses Pembelajaran di SMP Negeri 1 Painan Kabupaten Pesisir Selatan". Maka dapat disimpulkan: Kompetensi Pedagogik Guru PPKn Dalam Proses Pembelajaran di SMP Negeri 1 Painan Kabupaten Pesisir Selatan yaitu 37,74\% responden menjawab Sangat Setuju (SS), 43,51\% responden menjawab Setuju (S), 15,59\% responden menjawab Tidak Setuju (TS), dan 3,13\% responden menjawab Sangat Tidak Setuju (STS). Rata-rata pada 
kompetensi pedagogik guru PPKn sebesar 3,15 dengan TCR yang diperoleh 78,95\%.. Sehingga dapat disimpulkan bahwa jawaban siswa kelas VIII dan IX tentang kompetensi pedagogik guru PPKn dalam proses pembelajaran di SMP Negeri 1 Painan Kabupaten Pesisir Selatan sudah baik.

Berdasarkan kesimpulan diatas disarankan agar guru dapat meningkatkan kompetensi pedagogik guru dalam proses pembelajaran untuk memenuhi kebutuhan peserta didik sehingga peserta didik sukses dalam belajar. Lembaga sekolah atau kepala sekolah harus berperan dalam membantu guru dalam mengembangkan kompetensi pedgogik dan melakukan evaluasi dan penilaian.

\section{Ucapan Terima Kasih}

Peneliti mengucapkan terima kasih kepada para siswa yang telah membantu penulis dalam memberikan jawabannya berupa angket dan mengumpulkan data penelitian serta ucapan terima kasih kepada kepala sekolah dan guru-guru yang telah memberikan peneliti izin untuk melakukan penelitian di Sekolah SMP Negeri 1 Painan Kabupaten Pesisir Selatan. Semoga artikel ini dapat bermanfaat bagi para pembaca serta peneliti dan para informan.

\section{Daftar Pustaka}

Anifa Alfia Nur. (2014). Meningkatkan Kompetensi Pedagogik Guru Di SD Yayasan Mutiara Gambut. Jurnal Administrasi Pendidikan Vol. 2 No. 1 Hal 65-831.
Ausnita. (2015). Kompetensi Pedagogik Guru di SMP Negeri 1 dan 2 Kecematan Nan Sabaris Kabupaten Padang Pariaman (Studdy Komparatif Senior dan Guru Junior). Jurnal Administrasi Pendidikan Vol. 3 No. 1 Hal. 664759.

Musfah, Jejen. (2011). Peningkatan Kompetensi Guru: Melalui Pelatihan Dan Sumber Belajar Teori Dan Praktik. Jakarta: Kencana Prenada Media Group.

Ninik Sumiarsi. (2015). Analisis Kompetensi Pedagogik dan Pengembangan Pembelajaran Guru SD Negeri 041 Tarakan. Jurnal Kebijakan dan Pengembangan Pendidikan Vol. 3 No. 1 Hal 99-104.

Peraturan Menteri Pendidikan Nasional Republik Indonesia Nomor 16 Tahun 2007 Tentang Standar Kualifikasi Akademik dan Kompetensi Guru.

Rifma. (2013). Promlematika Kompetensi Pedagogik Guru Sekolah Dasar. Jurnal Ilmiah Ilmu Pendidikan Vol. XIII No.1.

Rifma. (2016). Optimalisasi Pembinaan Kompetensi Pedagogik Guru. Jakarta: Kencana.

Undang-undang Republik Indonesia Nomor 14 Tahun 2005 tentang Guru dan Dosen. 